Anna Stepčenko, Laura Jaunromāne

\title{
lesaistītās/ieinteresētās puses sociālo pakalpojumu organizāciju personāla un pakalpojumu galalietotāju spēcināšanā. Teorētisks ieskats un SEMPRE projekta empīrisko datu analīze
}

\author{
Stakeholders of Social Service Provider \\ Organisation Staff and End User Empowerment. \\ Theoretical Insight and Analysis of Project \\ SEMPRE Empirical Data
}

\section{Summary}

The aim of this article is to highlight the role of the stakeholders in social empowerment process and to characterize them as a tool of empowerment.

The article contains analysis of both theoretical aspect and empirical data characterising stakeholders' participation in the local empowerment networks of the eight Baltic sea region countries. The authors have implemented a theoretical analysis of stakeholders as a concept, its development, as well as the usual framework of the stakeholders' analysis is provided. The contemporary meaning of stakeholders is explored according to R. Edward Freeman, the theorist of business management, as viewed in his book "Strategic Management: A Stakeholder Approach" (1984). It has become a landmark within fields of business and third sector. Many significant contemporary international organizations work in cooperation with their stakeholders. Those aspiring to protect general human ethical values include the United Nations Organization, World Health Organization, World Wildlife. The framework of stakeholders' analysis consists of three parts: 1 . identifying stakeholders, 2 . differentiating and categorizing stakeholders, 3 . investigating relationships between stakeholders. 
An empirical information on stakeholders of the SEMPRE project partners has been gathered at the very beginning of the project. A questionnaire was distributed among the partners. The content of the questionnaire consisted of information on status of stakeholders, their aims, resources, functions, and roles in the relevant Local Empowerment Network (LEN) and Regional Coordination Group (RCG), and, finally, their contact information.

As a result, there were received 17 completed questionnaires that contained information about 168 stakeholders. The main findings of the stakeholders' analysis of the SEMPRE project partners are being related to levels and types of stakeholders. Three levels of stakeholders were defined - those representing national, regional and local levels, as well seven types of stakeholders: 1. policy and decisions makers, 2. policy implementing stakeholders, 3. educational and research institutions, 4. professional education institutions, workshops, day care centers, 5. non-governmental organizations and their networks, 6. entrepreneurs, 7. individuals (relatives, friends).

The aims of stakeholders depend on the level and type they belong to. The classification of aims ranges from general social policy promotion to specific education, life-long learning, support, and philanthropy.

The resources at their disposal similarly depend on their level and type. They are placed in a scale including establishment of social policy, legislative regulations, impact on mass media, knowledge and experience to share, rooms and places to offer an emotional closeness for the end users.

Roles of the project SEMPRE stakeholders are divided into social policy makers, decision makers, educators, experts, consultants, researchers, analysts, leaders of opinions, supporters, involvers. Encouraging is also an important role for the end users. The most widespread functions are an exchange of knowledge, consultations, sharing experience.

Key words: stakeholders, empirical data on their aims, resources, functions, roles.

\section{Kopsavilkums}

Raksta mērķis ir teorētiski izskaidrot, ko nozīmē jēdziens "iesaistītās/ieinteresētās puses”, un analizēt empīriskos datus par SEMPRE projektā iesaistītām/ ieinteresētām pusēm. Jēdziena stakeholders, kas latviešu valodā visbiežāk tiek tulkots kā "iesaistītās puses”, saturiskā log̣ika liek tā nozìmes precizēšanai pievienot apzīmējumu "ieinteresētās puses". Tādēl šai izdevumā tiek lietots jēdziens "iesaistītās/ieinteresētās puses". Sākumā tiek sniegta jēdziena definīcija, tad aplūkotas jēdziena saturiskās nozīmes pārmaiņas laika gaitā un tā mūsdienu saturs. Šì raksta kontekstā iesaistītās puses ir sociālās spēcināšanas aǵenti. Teorētisko ieskatu turpina projekta partneru sniegtās empīriskās informācijas analīze par iesaistītām/ieinteresētām pusēm, par šo pušu lokālo spēcināšanas tīklu sadarbību un pakalpojumu galalietotāju iesaistǐšanu sociālo pakalpojumu veidošanā. 168 uzrādìto iesaistīto/ieinteresēto pušu analīzes 
rezultātā ir radīta tipolog̣ija, ko veido septiņi iesaistīto/ieinteresēto pušu tipi. Ir analizēti iesaistīto/ieinteresēto pušu mērḳi, resursi un lomas sociālās spēcināšanas procesā.

Atslēgvārdi: iesaistītās/ieinteresētās puses - jēdziena definīcija, saturs un attīstība, empīriskie dati par iesaistīto pušu tipiem, funkcijām, mērḳiem, resursiem un lomām.

Tematika. Jēdziena “iesaistītās/ieinteresētās puses” saturs, iesaistīto/ieinteresēto pušu analīzes struktūra. Sociālās spēcināšanas jēdziens iesaistīto/ieinteresēto pušu kontekstā. Empīrisko datu par SEMPRE partneru iesaistītām/ ieinteresētām pusēm analīze. Iesaistīto/ieinteresēto pušu varas kapitāla un darbības līmeṇa raksturojums. Iesaistīto/ieinteresēto pušu mērķu raksturojums. Iesaistīto/ieinteresēto pušu tipologija, resursi un lomas.

\section{Jēdziena "iesaistītās/ieinteresētās puses" saturs}

Šì iztirzājuma centrālais jēdziens un temats ir "iesaistītās/ieinteresētās puses”. Ar šo jēdzienu Rietumu autori vadīšanas teorijā un pārvaldības praksē apzīmē visu to dažkārt l̦oti plašo grupu, institūciju un arī indivīdu kopumu, tai skaitā lobiju, kas kaut kādā mērā ir iesaistīts, iesaistījies un/vai ieinteresēts notikumu vai kāda procesa gaitā, lai to ietekmētu sev vēlamā virzienā. Iesaistīto/ieinteresēto pušu mērḳis var būt arī iegūt zināšanas, kā dažādi masu vai grupu ietekmēšanas līdzekḷi ietekmē grupu apziņu, uzvedību un rīcību.

Vārds stakeholder angḷu valodā ir saliktenis, kas cēlies no vārdiem stake un holder. Abiem vārdiem, kā tas bieži mēdz būt angḷu valodā, ir daudzas un visai atškirīgas nozīmes, un vārda viena un tā pati forma var būt gan lietvārds, gan darbības vārds. Vārds stake var tikt tulkots kā "stabs", "miets", "atbalstìt ar stabu/mietu" vai arī kā "likme kāršu spēlē", "likt uz spēles". Vārds holder var tikt tulkots kā "tvēriens", “ietekme”, "pakḷaut ietekmei”, "pārvaldīt”, "būt ìpašniekam”, "izturēt”, "atturēt", "vadīt sapulci" u. c. Sākotnēji ar vārdu stakeholder ir saukts, apzīmēts cilvēks, kas liek likmes kāršu spēlē vai derībās. Vēlāk ar vārdu stakeholder sākts apzīmēt akciju vai paju ìpašnieku uzṇēmējdarbībā. Mūsdienās uzņēmējdarbības un citu sektoru vadīšanā ar jēdzienu stakeholder apzīmē visus, kas ir ieinteresēti un iesaistīti kādā notikumā un/vai norisē un mēgéna to ietekmēt. Iesaistītie/ieinteresētie var būt visu līmeṇu institūcijas, organizācijas un/vai indivīdi. Iesaistītie var 
būt ieinteresēti norisi ārēji un iekšèji veicināt un atbalstìt, kā arī kavēt, likt šḳēršlus, ja norise tiem nav izdevīga, tātad neatbilst šo darbojošos aktoru interesēm. Latviešu valodā jēdziens stakeholder tiek tulkots dažādi. To tulko kā 1) "iesaistītās puses", 2) "ieinteresētās puses", 3) "norisē iesaistījušies aktori” (anglu val. actors), 4) vēl cits veids, kā mēdz dēvēt iesaistījušās institūcijas, organizācijas, sociālās grupas un/ vai indivīdus, ir "iesaistītās/ieinteresētās aǵentu grupas" - tā jēdzienu stakeholder savā promocijas darbā tulkojusi Viola Korpa $(2012,65)$ un vēlāk pati to atzinusi par "diezgan smagnēju apzīmējumu". Tādēl, lai saprastu konkrētam gadījumam atbilstošāko jēedziena nozīmi, ir jāpārzina tematiskais lauks un jāzina konteksts, kurā jēdziens tiek lietots. Šai rakstā atbilstoši temata saturam lietosim jēdzienu "iesaistītās/ieinteresētās puses" kā jēdziena stakeholder saturam atbilstošāko atveidojumu latviešu valodā.

\section{Iesaistīto/ieinteresēto pušu analīzes struktūra}

Iesaistìto/ieinteresēto pušu analīze vadīšanas jomā ir plaši izmantota metode, ko sāka lietot 19. gadsimtā biznesa vidē. Vēl plašāk to sāka izmantot uzṇēmējdarbībā 20. gadsimta 30. gados, lai uzlabotu attiecibas ar sabiedrību un palielinātu uzṇēmēju peḷnu. Sākotnēji iesaistītās puses tika apzīmētas arī ar jēdzienu shareholders vai stockholders. Šai gadījumā šo vārdu saturs ir tiešs un skaidrs. Tas ir šaurs grupējums, tātad biznesa uzṇēmuma īpašnieku grupas jeb daḷu turētāji, kuri piedalās biržu spekulācijās un kuru galvenās, ja ne vienīgās intereses ir gūt peḷnu. 60. gadu beigās transnacionālās uzṇēmumu kompānijas ievieš jēdzienu stakeholders, jo vairākas universālas transnacionālas un pārnacionālas organizācijas, jo īpaši Apvienoto Nāciju Organizācija, iestājas par universālām cilvēciskām tiesībām un vērtībām, pārredz un prognozē attīstỉbas tendences. Tādēl tās paplašina vērtîbu izpratni, iesaka ieviest normatīvu kontroli pār uzṇēmējdarbību, radot korporatīvās sociālās atbildības jēdzienu un lietojot jaunu pieeju uzṇēmējdarbības regulēšanai. Tādējādi tiek būtiski paplašināts ieinteresēto pušu loks. Korporatīvā sociālā atbildība nozīmē pel̦nas intereses sasaistīt ar dabas vides piesārṇošanas ierobežošanu un ņemt vērā sabiedrības intereses, jo abas šìs vides - dabas vide un sociālā vide (galvenokārt 
algotais darbaspēks un tā atalgojuma lìmenis) - ir pamatresursi un galvenie avoti, kas rada peḷnu. Pel̦nas gūšanu kā vienīgo vai galveno uzṇēmējdarbỉbas motīvu ierobežo uznēēmēju rīcību regulējošas normas likumdošanā, ètiska standarta regulas un starptautiskas normas. Tādējādi būtiski paplašinās rīcību regulējošais ietvars un iesaistīto/ ieinteresēto pušu skaits. Amerikāṇu biznesa administrēšanas teorētikis Roberts Edvards Frīmens (Freeman, 2010) apraksta un analizē jēdziena "iesaistītās puses" izcelsmi un attīstību.

R. E. Frīmens lieto jaunu pieeju iesaistīto/ieinteresēto pušu analīzei un ievērojami paplašina šauro iesaistīto/ieinteresēto uzņēmuma īpašnieku loku. Iesaistīto/ieinteresēto pušu korpusā ražošanas sfērā tagad ir iekḷautas valdības iestādes, politiskās partijas, uzṇēmējdarbības asociācijas, arodbiedrības, iedzīvotāju kopienas, finansisti/investori, piegādātāji, darba devēji, darba ņēmēji, patērētāji un arī konkurenti.

Frīmens definē jēdzienu "iesaistītās/ieinteresētās puses" kā grupas un indivīdus, kuri tiek ietekmēti un paši ietekmē konkrētus procesus. Iesaistītās/ieinteresētās puses tātad ir jebkuras identificējamas personu grupas un viṇu pārstāvētās institūcijas, kas ietekmē uzņēmuma izdzīvošanu un nākotni. Tāda ir vienkāršā definīcija, kas îsā formā izsaka lietas būtību.

20. gadsimta 80. gados kā stratēgiskās vadī̌anas pieeja tiek izstrādāta iesaistìto/ieinteresēto pušu teorija, kas attīstās joprojām, jo tai pievēršas aizvien vairāk autoru un praktiskās lietojamības dẹl tā kḷūst populāra visās nozīmīgākajās darbības sfērās, kur jāpieņem lēmumi par attīstîbas plāniem un rīcību, lai tos īstenotu. Tātad iesaistīto/ieinteresēto pušu matricas kā universālu situācijas analīzes instrumentu ir lietderīgi lietot uzņēmējdarbībā, sabiedrības un valsts pārvaldībā, starptautiskā politikā, sociālā politikā, veselíbas aprūpes politikā, jebkuras citas nozares politikā un aktivitātēs, kā arī bezpel̦nas sabiedrisko organizāciju darbībā. Daudzas nozīmīgas starptautiskas organizācijas - Apvienoto Nāciju Organizācija, Pasaules Veselības organizācija, Pasaules Dabas fonds - un starptautiskās profesionālās asociācijas lieto iesaistīto/ieinteresēto pušu analīzes metodi un ir izstrādājušas saviem mērḳiem piemērotas vadlīnijas iesaistīto/ieinteresēto pušu analīzei. Paplašinātu iesaistīto/ieinteresēto pušu jēdzienu 1996. gadā ir lietojis tālaika britu premjerministrs Tonijs Blērs (Tony Blair), aicinot veidot iesaistīto/ieinteresēto pušu ekonomiku (stakeholder economy), kurā tiktu iesaistītas visas sabiedrības grupas (Davies, 1996). 
Iesaistīto/ieinteresēto pušu teorijā tiek ieteikts iesaistītās/ieinteresētās puses analizēt noteiktā log̣iski strukturētā secībā (Reed, 2009; Gijselinckx, 2009, 4, 6). Ieteiktās secīgās darbības ir šādas:

- identificēt iesaistītās/ieinteresētās puses, tas nozīmē noteikt, kas ir iesaistītās/ieinteresētās puses un ko tās dod;

- tipolog̣izēt jeb klasificēt iesaistītās/ieinteresētās puses, tas nozìmē sadalìt tās dažādos tipos saskaṇā ar to varas pilnvarojumu;

- noteikt un izprast iesaistīto/ieinteresēto pušu mijiedarbību un savstarpējās attiecības.

Lai identificētu iesaistītās/ieinteresētās puses, var izmantot dažādas metodes. Tās var būt fokusgrupu intervijas, daḷeji strukturētas intervijas, sniega bumbas metode, eksperta analīze. Kad iesaistītās/ieinteresētās puses ir identificētas, iespējams veidot to tipologiju un savstarpējo attiecību karti pēc to vietas varas hierarhijā un tām esošã varas resursa, pēc to racionalitātes līmeņa vai egocentriskām pretenzijām un spējas raisìt dialogu, kā arī pēc kritiskuma, iztirzājot iesaistīto/ieinteresēto pušu intereses, lomu lēmumu pieņemšanā un nozīmīgumu saikṇu un attiecību veidošanā. İsumā tas viss nozīmē ietekmēšanas un ietekmes potenciāla izvērtēšanu. Veidojot iesaistīto/ieinteresēto pušu tipoloǵiju, var izmantot analītisko pieeju, izkārtojot iesaistītās/ieinteresētās puses hierarhiskā kārtībā pēc to funkcijām un varas resursa, lomām politikas veidošanā un lēmumu pieṇemšanā. Iesaistīto/ieinteresēto pušu savstarpējo attiecību noskaidrošanā var veidot un lietot mijiedarbības matricas, izmantot zināšanu kartēšanu, sociālā tîkla analīzi.

Konkrēta iesaistīto/ieinteresēto pušu apzināšana un analīze ir veikta SEMPRE projektā. Eiropas Savienības Interreg Baltijas jūras regiona valstu programmas SEMPRE projekta pamatmērḳis ir sociālo pakalpojumu organizāciju personāla un sociālo pakalpojumu galalietotāju sociālā spēcināšana. Lai šo mērḳi sasniegtu, ir apzinātas sociālo pakalpojumu lietotāju vajadzības un izzinātas barjeras un šḳēršlı sociālo pakalpojumu sniegšanas organizāciju darbā. Pēc iegūtās informācijas apkopošanas lokālie spēcināšanas tīkli mikroprojektu veidā pārbaudīja praksē instrumentus, pieejas, metodes, lai pārliecinātos par to, vai organizācijas, kas sniedz sociālos pakalpojumus, reǵionos kḷūst spēcīgākas un varētu sociāli spēcināt sociālo pakalpojumu saṇēmējus jeb lietotājus. Sākot īstenot projektu, viens no pirmajiem darbiem bija iegūt informāciju par tās vietas, kur darbojas lokālais spēcināšanas tìkls, 
sociālekonomisko kontekstu, kā arī par iesaistītām/ieinteresētām pusēm jeb aktoriem, kas ietekmē darbu ar konkrēto sociālo pakalpojumu lietotāju grupu (tās bija izvēlētas vairākas un dažādas), kā arī analizēt iesaistītās/ieinteresētās puses. Iesaistīto/ieinteresēto pušu analīze šai projektā ir vajadzīga saistībā ar tā pamatmērḳi - spēcināt sociālo pakalpojumu sniedzējus, kas varētu īstenot spēcināšanas ideju, iesaistot savas dzīves kvalitātes uzlabošanā sociālo pakalpojumu galalietotājus.

\section{Sociālās spēcināšanas jēdziens iesaistīto/ieinteresēto pušu kontekstā}

Sociālās spēcināšanas jēdziens ir attīstìts tajā pašā laikā, kad radās iesaistīto pušu jēdziena mūsdienu izpratne. Tas nonāca sarunu tematu, diskursu un sociālo protesta akciju apritē pagājušā gadsimta 60. gadu beigās. Vēlāk tas kḷuva par plaši lietotu jēdzienu, kas ietver ideju, ka tiesības uz varu ir arī vājām, mazāk aizsargātām sociālām grupām un ka tās var ietekmēt varas lēmumus. Tā kā stratificētā sabiedrībā sociālo grupu intereses ir l̦oti atšķirīgas, tad varas lēmumu ietekmēšanai ir izveidota pat speciāla oficiāli atzīta institūcija, saukta par lobēšanu, lobiju. Leg̣itimitāti ieguva ideja par nepieciešamību notikumos un norisēs un to apspriešanā iesaistìt vājās, viegli ievainojamās, maz aizsargātās sociālās grupas, jo īpaši tad, kad lēmumi varas institūcijās ietekmē vinu dzīves apstākḷus. Arī šĩs sociāli vājās grupas tāpat kā ekonomiski spēcīgās sociālās grupas var pārstāvēt lobijs.

\section{Iesaistīto/ieinteresēto pušu empīrisku datu analīze}

2016. gada aprìlī SEMPRE projekta partneri tika lūgti identificèt iesaistītās puses, kas ietekmē sociālo pakalpojumu piedāvājumu galalietotājiem, un aizpildìt tiem izsūtīto anketu, lai partneru datus varētu apkopot. Anketā tika iekḷautas šādas informatīvas sadaļas: 1) iesaistìtās/ieinteresētās puses nosaukums; 2) îss apraksts par to, ar ko tā nodarbojas; 3) iesaistītās/ieinteresētās puses mērḳis vai intereses par SEMPRE partneri; 4) kādus resursus iesaistītās/ieinteresētās puses spēj 
Tabula

Projekta partneru atrašanās vieta, galalietotāji un iesaistīto pušu skaits

\begin{tabular}{|c|c|c|c|}
\hline $\begin{array}{l}\text { Projekta } \\
\text { partnera } \\
\text { Nr. }\end{array}$ & $\begin{array}{c}\text { Vieta, kur darbojas vietējais } \\
\text { spēcināšanas tīkls vai reggionālā } \\
\text { koordinācijas grupa }\end{array}$ & $\begin{array}{l}\text { Sociālo pakalpojumu } \\
\text { galalietotāju kategorijas }\end{array}$ & $\begin{array}{c}\text { lesaistīto/ } \\
\text { ieinteresēto } \\
\text { pušu skaits }\end{array}$ \\
\hline 1. & $\begin{array}{l}\text { Ditmāršene (Dithmarschen), } \\
\text { Vācija }\end{array}$ & Viena vecāka gimenes & 12 \\
\hline 2. & Plēne (Plön), Vācija & $\begin{array}{l}\text { Ilgtermina bezdarbnieki, } \\
\text { kam ir gُimene }\end{array}$ & 8 \\
\hline 3. & $\begin{array}{l}\text { Ziemelffrīzlande } \\
\text { (Nordfriesland), Vācija }\end{array}$ & Bēgli un imigranti & 10 \\
\hline 4. & $\begin{array}{l}\text { Esterbotena (Österbotten), } \\
\text { Somija }\end{array}$ & $\begin{array}{l}\text { Vecāka gadagājuma } \\
\text { personas }\end{array}$ & 7 \\
\hline 5. & $\begin{array}{l}\text { Kokola (Kokkola) un Pietarsāri } \\
\text { (Pietarsaari), Somija }\end{array}$ & $\begin{array}{l}\text { Migranti, kas ir } \\
\text { ilgtermiņa bezdarbnieki }\end{array}$ & 6 \\
\hline 6. & - & - & \\
\hline 7. & $\begin{array}{l}\text { Grobinsa, Bārta, Dubeñi, } \\
\text { Rucava, Durbe, Liepāja. } \\
\text { Kurzemes reǵions, Latvija }\end{array}$ & $\begin{array}{l}\text { Pieaugušas personas ar } \\
\text { invaliditāti }\end{array}$ & 27 \\
\hline 8. & - & - & \\
\hline 9.1. & Jurbarka (Jurbarkas), Lietuva & Viena vecāka giimenes & 3 \\
\hline 9.2. & Paǵēgi (Pagègiai), Lietuva & Vielatkarīgās personas & 4 \\
\hline 10.1 & $\begin{array}{l}\text { Harkujerve (Harkujärve), } \\
\text { Igaunija }\end{array}$ & $\begin{array}{l}\text { Ģimenes ar bērniem. } \\
\text { No ieslodzījuma } \\
\text { atbrīvotas personas }\end{array}$ & 14 \\
\hline 10.2 & $\begin{array}{l}\text { Austrumviru aprink,kis (Ida- } \\
\text { Virumaa), Igaunija }\end{array}$ & $\begin{array}{l}\text { Ģimenes un personas ar } \\
\text { invaliditāti }\end{array}$ & 15 \\
\hline 11.1. & $\begin{array}{l}\text { Veru apriņķis (Võrumaa), } \\
\text { Igaunija }\end{array}$ & Ģimenes ar bērniem & 14 \\
\hline 11.2 & $\begin{array}{l}\text { Pelvas apriņķis (Põlvamaa), } \\
\text { Igaunija }\end{array}$ & Ģimenes ar bērniem & 6 \\
\hline 12. & Ričivola (Ryczywót), Polija & Jaunieši & 5 \\
\hline 13. & $\begin{array}{l}\text { Norbotena (Norrbotten), } \\
\text { Zviedrija }\end{array}$ & $\begin{array}{l}\text { Jaunieši bez darba } \\
\text { ar zemu, nepabeigtu } \\
\text { izglītību }\end{array}$ & 7 \\
\hline 14. & $\begin{array}{l}\text { Ėvertornjo (Övertorneå), } \\
\text { Zviedrija }\end{array}$ & $\begin{array}{l}\text { Migranti, kas iecel̦ojuši } \\
\text { nesen un kam nav } \\
\text { uzturēšanās aț̦auju }\end{array}$ & 9 \\
\hline 15. & $\begin{array}{l}\text { Tendere (Tønder) un Varde } \\
\text { (Varde), Senderjitlande } \\
\text { (Sønderjylland), Dānija }\end{array}$ & Bēgli & $5+4$ \\
\hline 16. & - & & \\
\hline 17. & Vidzemes regions, Latvija & $\begin{array}{l}\text { Jaunieši ar zemu } \\
\text { izglīitibu, bez prasmēm } \\
\text { un darba }\end{array}$ & 12 \\
\hline
\end{tabular}


piedāvāt; 5) kāda ir to loma - ko tās spēj izdarīt lokālā un reǵionālā tîkla spēcināšanā; 6) kontaktinformācija.

No partneriem tika saņemtas 17 aizpildìtas anketas. Aizpildìto anketu sarakstos iesaistīto pušu skaits bija no trīs (PP9 - 9. projekta partneris) līdz 27 (PP7). Kopējais iesūtīto iesaistīto/ieinteresēto pušu skaits ir 168. Daži projekta partneri strādā ar vairāk nekā vienu pakalpojumu galalietotāju grupu vai vairāk nekā vienā reǵionā, tāpēc trijos gadījumos partneri ir iesūtījuši divus sarakstus.

Dati par projekta partneru atrašanās vietu, viṇu galalietotāju grupām un iesaistītām/ieinteresētām pusēm, kurām ir lokālās spēcināšanas tìkli, ir apkopoti tabulā.

Iesaistīto/ieinteresēto pušu empīrisko datu analīze ir veikta divējādi - vispārīgi un konkrēti. Vispārīgi tiek raksturots iesaistīto/ ieinteresēto pušu tipologiskais iedalījums pēc darbības mēroga, līmeṇa, varas kapitāla un mērḳiem. Resursu piedāvājums un lomu raksturojums tiek piesaistīts konkrētam iesaistìto/ieinteresēto pušu tipam.

\section{Iesaistīto/ieinteresēto pušu varas kapitāla un darbības līmeņa raksturojums}

Iesaistītās/ieinteresētās puses pēc to funkcionēšanas mēroga, varas un ietekmes var iedalìt trīs līmeños:

1) valsts jeb nacionālā līmeṇa iesaistītās/ieinteresētās puses;

2) regionālā līmeṇa iesaistītās/ieinteresētās puses;

3) vietējā līmeṇa iesaistītās/ieinteresētās puses.

Šie līmeṇi norāda uz kontekstu, kādā iesaistītās/ieinteresētās puses darbojas, tomēr tie ne vienmēr ir nozīmīguma vai svarīguma rādītāji. Empīrisko datu analīzes rezultātā ir izveidota iesaistìto/ieinteresēto pušu tipologiija, kas sastāv no septiniem tipiem. Tie ir:

1) lēmumu pieṇēmēji, politikas veidotāji;

2) politikas ìstenotāji;

3) izglìtības un pētniecības institūcijas;

4) darbnīcas, radošie centri, dienas centri;

5) nevalstiskās organizācijas un to sadarbības tīkli;

6) uzñēmēji;

7) individuālas personas. 
Analīzes procesā atsevišķas iesaistītās/ieinteresētās puses ir atzīmētas kā piederīgas pie diviem tipiem, tomēr lielākoties katra iesaistìtā/ieinteresētā puse ir tipolog̣izēta atbilstoši tās galvenajai funkcijai. Acīmredzams izṇēmums ir pašvaldības, kas ir gan nacionālās, gan lokālās politikas realizētājas.

Nacionālā līmeņa iesaistītās/ieinteresētās puses ir dažādas ministrijas, valsts komisijas, organizācijas un aǵentūras, piemēram, nodarbinātības ağentūras un integrācijas fondi, šo organizāciju reg̣ionālie biroji, piemēram, Nodarbinātības valsts dienesta birojs pašvaldībā var būt attiecināms uz regionāla vai vietēja līmeņa iesaistīto pušu partnerību. Regionu vai pašvaldību domes un sociālie dienesti atkarībā no valsts administratīvā iedalījuma un pārvaldes organizācijas attiecināmi uz reǵionālo vai vietējo līmeni. Nevalstiskās organizācijas un uzṇēmumi var darboties visos trijos līmeņos, tāpat arī izglìtības institūcijas, piemēram, vietējā skola un nacionāla mēroga universitāte. Darbnīcas, vietējo kopienu organizācijas un apvienības, indivīdi strādā kā vietējā līmeņa iesaistītās/ieinteresētās puses. Dažādie līmeņi norāda uz mēroga kontekstu, kādā iesaistītās/ieinteresētās puses visbiežāk darbojas.

Kopumā partneru iesūtītajos sarakstos tika identificētas 33 nacionālā līmeņa iesaistītās/ieinteresētās puses, 38 reǵionālā līmeņa iesaistītās/ieinteresētās puses (tajā skaitā viena gan nacionālajā, gan reǵionālajā līmenī un astoṇas gan reǵionālajā, gan vietējā līmenī) un 106 vietêjā līmeṇa iesaistītās/ieinteresētās puses. Tā kā projekts ir orientēts uz vietējā līmeņa sadarbỉbas tỉkla veidošanu un mikroprojektu izveidi, tad vietējā līmeṇa iesaistītās/ieinteresētās puses partneru sarakstos dominē.

Reǵionālais un vietējais līmenis dažkārt var būt grūti nodalāms, tas atkarīgs no pārvaldes sistēmas un administratīvā iedalījuma, kas dažādās valstīs atšķiras. Vācijā katrai federālajai zemei ir sava federālā valdība ar tai atbilstošām funkcijām, piemēram, Šlēsvigas-Holšteinas Sociālo lietu, veselības, zinātnes un vienlīdzības ministrija (SchleswigHolstein Ministry for Social Affairs, Health, Science and Equality) ir reǵionālā līmeṇa iesaistītā/ieinteresētā puse. Latvijā nākamais pārvaldes līmenis pèc valsts līmeņa ir vietējā līmeņa pašvaldības, piemēram, Grobiņas, Priekules un Rucavas novada pašvaldības, kas atrodas Kurzemes reǵionā, kurš ir klasificēts kā statistikas reǵions, bet tam nav pārvaldības statusa. Visos trijos iesaistīto/ieinteresēto pušu līmeņos tiek veidota politika, pieņemti lēmumi un sadalīti un pārdalīti līdzekḷi. 


\section{6. lesaistīto/ieinteresēto pušu mērķu raksturojums}

Nacionālā līmeņa iesaistītām/ieinteresētām pusēm mērḳi ir vispārīgāki. Valsts ministrijas par savu misiju uzskata iedzīvotāju dzīves apstākḷu uzlabošanu tajās jomās, kas ir to pārvaldībā. Ministriju pakḷautībā esošās valsts ağentūras îsteno ministriju izvirzìto mērḳu sasniegšanu. Piemēram, Vaivaru Tehnisko palīglīdzekḷu centra mērḳis ir nodrošināt tehnisko palīglīdzekḷu pakalpojumus atbilstoši valsts finansētajām kvotām personām ar invaliditāti. Domājot par sadarbību ar šo iesaistīto/ieinteresēto pusi, projekta vadītājam jāṇem vērā, ka šis organizācijas resursi nevar tikt izlietoti tikai vietējā līmenī, tai jānodrošina pakalpojumi visiem tiem valsts iedzīvotājiem, kam tie ir nepieciešami. Tajā pašā laikā valsts aǵentūru reǵionālajiem birojiem ir izvirzīti mērḳi tieši zemāka līmeṇa administratīvām vienībām. Piemēram, Vācijas Federālai nodarbinātības ag̣entūrai reǵionālie biroji ir četrās apdzīvotās vietās (Job Centers Nordfriesland in Sylt, Wyk of Fohr, Husum, Breklum, Tonning, Leck and Niebull). Iesaistīto/ieinteresēto pušu vadībā ir būtiski saprast organizāciju hierarhiju un varas sadalījumu, kā arī atrast un izcelt kopīgos projekta un attiecīgās organizācijas mērḳus.

Izglìtības institūciju mērḳi var būt, piemēram, "atbalstìt ilgtspējīgu lauku regiionu attīstību” (to veic Šlēsvigas-Holšteinas federālās zemes lauku teritoriju akadēmija (Akademie für die ländlichen Räume Schleswig-Holsteins e. V.) vai "mācīt bēglus" (Dānijas Sprogskole). Universitāšu un pētniecības centru mērḳi var būt sasniedzami starptautiskā, nacionālā, reg̣ionālā līmenī. Bet pamatskolas mērḳis nodrošināt "izglìtības pieejamību un kvalitāti” (kā to Igaunijā definē iesaistītā/ ieinteresētā puse - Harkujärve Põhikool) attiecināms uz vietējo līmeni. Lai arī izglîtības un pētniecības institūciju mērḳi var būt definēti loti vispārīgi, kā "izglìtība un pētniecība" (piemēram, iesaistītās/ieinteresētās puses Luleå tekniska universitet un Syddansk Universitet), tās var sniegt atbalstu projektam vairākos nozīmīgos jautājumos - pētījumos, konsultācijās, tēmas aktualizēšanā un diskusijas veidošanā.

Darbnīcas, radošie centri, dienas centri par savu mērḳi izvirza dažādas "mūžizglìtỉbas aktivitātes" un lielākoties darbojas vietējā līmenī, jo viena no šādu centru būtiskajām priekšrocībām ir ērta piekḷuve, tuvums dzivesvietai.

Nevalstiskās organizācijas un uzṇēmēji savus mērķus var attiecināt uz visiem trim iesaistīto/ieinteresēto pušu līmeņiem. Nevalstisko 
organizāciju mērḳi parasti ir domāti kādas nelabvēlīgā situācijā esošas sociālas grupas interešu pārstāvībai, piemēram, "veicināt vājredzīgu un neredzīgu cilvēku integrāciju sabiedrībā, vinu interešu aizstāvību un dzīves kvalitātes celšanu" (Liepājas Neredzīgo biedrība), "gimene kā labākā vide, kur bērnam uzaugt” (Igaunijas NVO Igale Lapsele Pere), "uzlabot dzīves apstākḷus lauku reǵionos, veicināt izglìīibu un apmācību, it īpaši sievietēm lauku reǵionos" (Vācijas NVO LandFrauenVerband Schleswig-Holstein e. V.), "palīdzēt veicināt gados jaunu migrantu nodarbinātību” (Somijas NVO Ehjä Ry).

Baznīcas organizāciju, it īpaši diakoniju, mērḳi ir saistīti ar kalpošanas misiju un vērsti uz līdzcilvēku atbalstīšanu. Tie ir definēti daudzējādi: "marginalizētu cilvēku spēcināšana, piedāvājot sociālos pakalpojumus lauku reǵionos (Vācijas NVO Diakonie Plön-Segeberg), "veidot dzīvošanai cien̄igu vidi" (Vācijas NVO Ortskirchen) vai "baznīcas atbalsts g̛̣imenēm un indivīdiem, kas nonākuši krīzē vai nedrošā situācijā" (Igaunijas NVO EELK Diakoonia - ja ühiskonnatöö talitusel).

Uzṇēmējdarbības mērkisis ir pel̦na, tomēr tas neizslēdz dažādi motivētu gribu iesaistīties aktivitātēs sociālās atbildības jomā vai labdarības pasākumos. Tāpat arī praktiska nepieciešamība pēc darbaspēka var būt viens no iemesliem, kāpēc uzṇēmējam ir interese iesaistīties kādā spēcināšanas projektā. Eiropas Savienības valstu nodokḷu likumdošana parasti atbalsta sociālo atbildību, kā arī ziedojumu vākšanu. Tāpat arī tāds uzṇēmējdarbības veids kā sociālā uzṇēmējdarbība veicina "nodarbinātību un nodarbinātības iespējas" iedzīvotāju grupām nelabvēlīgā situācijā. Strādājot ar iesaistītām/ieinteresētām pusēm, kas ir uzņēmēji, būtiski ir atrast to projekta aspektu, kas sniegtu labumu vinu biznesam. Tomēr sociālā atbildība var būt arī pašu uzṇēmēju mērḳis, piemēram, "profesionāla attīstība, filantropija" (Igaunijā uzṇēmums OÜ Garden).

\section{7. lesaistīto/ieinteresēto pušu tipologija, resursi un lomas}

Analizējot partneru datus, kopumā tika identificēti septiņi iesaistīto/ieinteresēto pušu tipi, taču katra partnera sarakstā nebūt nebija iekḷauti visi iesaistīto/ieinteresēto pušu tipi. Iesaistīto/ieinteresēto pušu identificēšana lauj noteikt to lomu un to rīcībā esošos resursus. 
Tādèjādi projekta partneriem ir vieglāk orientēties, kur tiem meklējami vajadzīgie resursi un palīgi.

Turpmāk ir sniegta projekta partneru informācija par vinuu iesaistītām/ieinteresētām pusēm to tipolog̣ijas secībā un saistībā ar šo aktoru resursiem un lomām.

1. Sociālās politikas veidotāju (ministriju, pašvaldību) resursi un lomas.

Sociālās politikas veidotāju līmenī partneri ir norādījuši šādas iesaistītās puses: Schleswig-Holstein Ministry for Social Affairs, Health, Science and Equality (PP1), Regional Council of Ostrobothnia (PP4), Labklājības ministrija (PP7), Ida-Viru County Government (PP10), Võru County Government (PP11), County Council of Norrbotten (PP13).

Resursi: iespēja noteikt un mainìt sociālo politiku, līdzekḷu pārdali un budžeta izmantošanu, līdzdalība Eiropas Savienības regulu un prasību, kā arī citu starptautisko normatīvu ieviešanā.

Iespējamā loma: savstarpējas konsultācijas, atbalsts procesu virzīšanai birokrātiskajā aparātā, ietekme uz mediju ieinteresētību un aktivitātēm.

2. Sociālās politikas īstenotāju (valsts institūciju un pašvaldību) resursi un lomas.

Iesaistītās puses: Kreis Dithmarschen (PP1), Jobcenter Plön (PP2), Job Centers Nordfriesland in Sylt, Wyk of Fohr, Husum, Breklum, Tonning, Leck and Niebull (PP3), Finnish Unemployment Office (PP5), Priekules novada Sociālais dienests / Social Department of Priekule County Municipality (PP7), Social Insurance Agency (PP13).

Resursi: ietekme uz politikas veidotājiem, specifiska normatīvā ietvara pārzināšana, zināšanas par sociālo pakalpojumu galalietotājiem un iespējām vinuus sasniegt, darba tirgus un regiionālā konteksta pārzināšana, statistiskas informācijas pārvaldība.

Iespējamā loma: konsultācijas, dalīšanās pieredzē, ekspertu pakalpojumi, pieejamo komunikācijas kanālu izmantošana sociālo pakalpojumu galalietotāju sasniegšanai un iesaistišanai, mobilizēšanai, arī uzṇēmēju sasniegšana un mobilizēšana, ja tas ir nepieciešams.

3. Izglīīibas un pētniecības institūciju (skolu, universitāšu, akadēmiju, pētniecisko institūtu) resursi un lomas.

Iesaistītās puses: Latvijas Universitāte (PP08), Academy of Economics for Rural Areas (PP1), Harkujärve Elementary School 
(PP10), Estonian University of Life Sciences (PP11), University of Economics (PP12), Luleå University of Technology (PP13), Tornedalens Folk High School (PP14), University of South Denmark (PP15).

Resursi: zināšanas par sociālajām teorijām, pètījumu metodēm un datu analīzi, pieeja datubāzēm, akadēmisks skatījums, pedagoğiska pieredze, telpu pieejamība.

Iespējamā loma: konsultācijas, viedokḷa līderība, sadarbības tìklu veidošana, līdzdalība jaunrades procesos, datu apkopošana un analīze, iekšēju un ārēju ekspertu piesaiste, atbalsts komunikācijas kanālu nodrošināšanā.

\section{Darbnīcu, radošo centru, dienas centru resursi un lomas.}

Iesaistītās puses: partneru iesūtītajos sarakstos šis iesaistìto/ieinteresēto pušu tips dažkārt minēts vispārīgi - kā "darbnīcas, radošie centri, mājražotāji (pārtikas ražošana, lauksaimniecibas ekologiskie, biolog̣iskie produkti, amatniecība)" un "dienas centri”.

Resursi: vieta aktivitātēm, aprīkojums un zināšanas par mācībām, mūžizglìtībai piemērotas telpas, tiešs kontakts ar sociālo pakalpojumu galalietotājiem, zināšanas un iemaņas darbā ar sociālo pakalpojumu galalietotājiem, izpratne un zināšanas par īpašām vajadzībām, praktiska pieredze.

Iespējamā loma: zināšanu apmaiņa, sociālo pakalpojumu galalietotāju iesaistǐšana, ekspertu zināšanu piedāvājums arodmācībās, dalīšanās ar labo prakšu piemēriem, līdzdalība jaunrades procesos.

\section{Nevalstisko organizāciju un to sadarbības tîklu resursi un lomas.}

Iesaistītās puses: LandfrauenVerband Schleswig-Holstein e.V. (PP1), Diakonie Plön-Segeberg (PP2), Paritatischer Wohlfahrtsverband Schleswig-Holstein e.V. (PP3), Finlands Svenska Socialförbund (PP4), Silta club (PP5), Apeirons (PP7), Pagegiai Anonymous Alcoholics Club Stiprybès šaltinis (PP9), Foundation for Social Action (PP10), Põlvamaa Association of Large Families (PP11).

Resursi: zināšanas par sociālo pakalpojumu galalietotājiem un viņu spēcināšanu, pieredze, sadarbības tīkls, kontakti, telpas, aprīkojums, zināšanas un iemaņas komandas darba veidošanā un sadarbības tīkla attīstišanā, organizatoriskas un komunikācijas prasmes, jomas autoritāte.

Iespējamā loma: viedokḷa līderi, konsultanti, sociālo pakalpojumu galalietotāju iesaistî̌ana, atbalsts mediju ieinteresēšanā, atbalsts 
sabiedriskajās attiecībās, pienesums diskusijās un spēcināšanas idejas iedzīvināšanā, darbs sadarbības tīklu veidošanā un vadīšanā, iespējama lìdzdalība pētijumu lauka darba stadijā.

\section{Uzņēmēju, tai skaitā sociālo uzņēmēju, resursi un lomas.}

Iesaistītās puses: Wirtschaftsförderungs-agentur Kreis Plön (PP2), Concordia (PP5), OÜ Garden (PP10), Samhall (PP13), Jokarjo (PP14).

Resursi: ekspertīze, zināšanas, pieredze, mentoru pakalpojumi, praktiska pieeja, potenciālas vai jau esošas darbavietas, potenciāli vai jau esoši pakalpojumi un produkti.

Iespējamā loma: konsultācijas, zināšanu aprite, pieredzes apmaiņa, sociālo pakalpojuma galalietotāju nodarbināšana, atbalsts uzñēmējdarbības pieejas izpratnei un uzsākšanai, komunikācijas prasmes un iemañas.

\section{Individuālo personu resursi un lomas.}

Iesaistītās puses: gimenes locekḷi, draugi, paziñas.

Resursi: zināšanas, pieredze, tuvums sociālo pakalpojuma galalietotājam.

Iespējamā loma: psiholog̣isks un informatīvs atbalsts un iedrošinājums, pieredzes un zināšanu apmaiņa.

Apkopojot empīrisko materiālu par partneru iesaistìtām/ieinteresētām pusēm, jāsecina, ka zināšanu un pieredzes apmaiņa, kā arī konsultācijas ir to biežāk minētie resursu un funkciju piedāvājumi. Konsultācijas, zināšanu un pieredzes apmaiṇa ir tas resurss, ar ko iesaistītās/ieinteresētās puses visbiežāk labprāt dalās. Tas nozīmē, ka veiksmīga komunikāciju platformas izveide ir būtisks priekšnosacījums, lai veidotos sadarbības tìkls, kurā informācijas, prasmju un ideju aprite varētu norisināties.

Katrai iesaistīto/ieinteresēto pušu grupai, pēc partneru sniegtajām ziņām, ir atšķirīgs resursu pienesums un atšķirīga funkcionālā loma. Kaut partneru sniegtajās ziņās tas nav minēts, tomēr noteikti jāṇem vērā praktiskā iespēja, ka var nākties sastapties arī ar tādu iesaistìto/ieinteresēto pusi, kas var likt šķērš̌lus sekmīgai darbïbai, var būt nelabvēlīga, kavēt darbu. Iespējamo konfliktu paredzēšana, novēršana un risināšanas prasme ir būtiska iesaistìto/ieinteresēto pušu vadīšanas procesā. Konfliktu prevencijā un intervencijā ir noderīgas komandas darba organizēšanas un komunikācijas prasmes, kas ir svarīgas arī tỉklošanās procesā.

Tīklošanās (networking) ir nozīmīgs atslēgvārds projekta partneru ziṇās par iesaistīto/ieinteresēto pušu funkcionālām lomām. Tiek 
izmantota jau esošo sadarbības tîklu pieredze un prasmes, kā arī veidoti jauni sociālie tīkli. Sadarbības tîkls ir nozīmīgs resurss, lai veidotu kopīgu projektu. Pašreizējo sadarbības tìklu pārstāvji var būt noderīgi konsultanti tieši komandas darba organizēšanā.

Analīze par iesaistìto/ieinteresēto pušu reālo veikumu lokālo spēcināšanas tìklu darbībā, to mijiedarbību un to savstarpējām attiecībām šajā pārskatā nav veikta, jo to kavē vairāku apstākḷu kopums. Pirmkārt, atšķirīgas ir partneru izvēètēs sociālo pakalpojumu galalietotāju grupas, otrkārt, astoṇās Eiropas Savienības Baltijas jūras reǵiona valstīs ir atšķirīgs likumdošanas ietvars un sociālekonomiskais konteksts. Tik apjomīgu analīzi nepiel̦auj veikt šī projekta mērḳi, uzdevumi un resursi. Taču vajadzības gadījumā to spēj izvērtēt katrs SEMPRE projekta partneris un lokālais spēcināšanas tīkls.

\section{Secinājumi}

Jēdziens “iesaistītās/ieinteresētās puses” ir izsenis lietots termins biznesa vadības vidē. Laika gaitā tā saturs ir paplašinājies un nozīme mainījusies. Mūsdienās šì plaši lietotā jēdziena galvenais saturs ir iesaistišanās, līdzdalība un griba ietekmēt notikumus un norises. Tā lietojums ir pārnests uz procesu vadīšanu visās darbības sfērās līdzịgi kā hrestomātiskā situācijas analīzes matrica.

Iesaistìto/ieinteresēto pušu analīze sastāv no trīs kanoniskām darbībām. Tās ir, pirmkārt, iesaistīto/ieinteresēto pušu identificēšana, otrkārt, iesaistīto/ieinteresēto pušu tipoloğijas izveide, treškārt, iesaistīto/ ieinteresēto pušu ietekmes spēka/pozīcijas noteikšana varas hierarhijā un savstarpējo attiecību diagnosticēšana.

Kopumā iesaistīto/ieinteresēto pušu apzināšana un iesaistī̌̌ana ir veiksmīgas darbỉbas un lietu gaitas svarīgs elements.

Sociālo pakalpojumu sniedzēju un galalietotāju sociālās spēcināšanas efektivitāte ir atkarīga no harmonijas pakāpes iesaistìto/ieinteresēto pušu attiecībās un mijiedarbībā. Citādas pieejas, metodes, jaunas zināšanas, kritiska domāšana spēcina abus aktorus - sociālo pakalpojumu sniedzējus un galalietotājus. Sociālā spēcināšana vājo un viegli ievainojamo sociālo grupu kontekstā nozīmē šo grupu piekḷuvi dažāda veida resursiem, arī varai, un lēmumu pieņemšanas ietekmēšanu. 
SEMPRE projekta partneru iesaistìto/ieinteresēto pušu empīisku datu analīze rāda, ka projekta īstenošanā piedalās visu līmeṇu iesaistītās/ieinteresētās puses. Tās pārstāv nacionālās, reǵionālās un lokālās varas institūcijas un visi sabiedrības funkcionālie sektori - valsts vara, uzņēmējdarbība un pilsoniskā sabiedrība.

Identificētie iesaistīto/ieinteresēto pušu mērḳi ir diapazonā no sociālās politikas veidošanas un tās ietekmēšanas līdz filantropijai un empātijai sociālās labklājības jomā. Biežāk minētie mērḳi ir izglītošana, zināšanu pārnese, mūžizglītỉba, pētniecība, darbavietu radīšana.

Identificētie iesaistīto/ieinteresēto pušu resursi arī ir atkarīgi no to tipa un darbības līmeņa. Vislielākie varas resursi sociālās politikas veidošanā un masu mediju ietekmēšanā ir pirmā līmeņa iesaistītām/ ieinteresētām pusēm. Konsultācijas, dažādu zināšanu un pieredzes apmaiņa ir tas resurss, kas tiek minēts visbiežāk, un ar to iesaistītās/ieinteresētās puses visbiežāk ir gatavas dalīties. Tîklošanās, telpu piedāvājums aktivitātēm, sociālās uzṇēmējdarbības iedibināšana un tuvība galalietotājiem ir citi izmantotie resursi.

Identificētās iesaistīto/ieinteresēto pušu lomas jeb funkcijas izriet no to tipa, darbỉbas līmeņa un resursiem. Biežāk SEMPRE projekta partneru minētās lomas ir lēmumu pieņēmèji, lobiji, vājo un viegli ievainojamo sociālo grupu advokāti, iesaistītāji daudzējādās aktivitātēs, viedokḷ līderi, izglìtotāji, eksperti, konsultanti, padomdevēji, atbalstītāji, iedrošinātāji.

Tā kā SEMPRE projekta savdabīga iezīme ir gan projekta partnerības valstu sastāva, gan sociālo pakalpojumu galalietotāju struktūras dažādība, tad iesaistīto/ieinteresēto pušu savstarpējo attiecību un mijiedarbības kvalitātes analīze ir paveicama vien lokāliem iesaistīto/ ieinteresēto pušu pārzinātājiem.

\section{leteikums}

Iesaistīto/ieinteresēto pušu iniciatīvas un iesaistǐšanās sociālos procesos spēj mainìt un uzlabot gan sociālo pakalpojumu sniedzēju, gan sociālo pakalpojumu galalietotāju situāciju sociālās labklājības jomā. Tādēl sociālo pakalpojumu organizāciju/dienestu vadībai un personālam ir lietderīgi log̣iski izsvērt, kādas iesaistītās/ieinteresētās 
puses vēlams piesaistīt sadarbībai, lai veicinātu atsevišķas pozitīvas pārmaiṇas un pozitīvo pārmaiṇu procesu kopumā.

\section{Atsauces}

Calves, A. E. (2009) Empowerment: The History of a Key Concept in Contemporary Development Discourse. Doi: 10.3917/rtm.200.0735.

Clayton, M. (2014) The Origin of Stakeholders. In: The Influence Agenda. Palgrave Macmillan, London.

Davies, G. (1996) Tony Blair Puts the Meat on the Stakeholder Bones. Available: http://www.independent.co.uk/news/business/tony-blair-puts-meat-on-thestakeholder-bones-1324167.html [accessed: October 27, 2017].

Freeman, R. E. (1984; 2010) Strategic Management: A Stakeholder Approach. Cambridge University Press.

Friedman, A. L., Miles, S. (2006) Stakeholders. Theory and Practice. Oxford: Oxford University Press.

Gijselinckx, C. (2009) Co-operative Stakeholders. Who Counts in Co-operatives, and How? Working Papers on Social and Co-operative Entrepeneurship. Catholic University of Leuven.

Korpa, V. (2012) Darba un ǵimenes dzīves saskaṇošana privātā sektora organizācijās. Promocijas darbs. Rīga: LU.

Ramirez, R. (1999) Stakeholder Analysis and Conflict Management. In: Buckles, D. (ed.) Cultivating Peace: Conflict and Collaboration in Natural Resource Management. Canada, Ottawa.

Reed, M. S. et al. (2009) Who's in and why? A typology of stakeholder analysis methods for natural resource management. Available: https://doi.org/10.1016/j. jenvman [accessed: October 27, 2017].

Schmeer, K. (n. d.) Stakeholder Analyze Guidelines. Available: http://www.who. int/workforcealliance/knowledge/toolkit/33.pdf [accessed: October 27, 2017].

SEMPRE project. Available: http://sempre-project.eu/about-the-project [accessed: October 27, 2017].

United Kingdom Government, Department for International Development. Guidance Note on How to do Stakeholder Analysis of Aid Projects and Programmes (1995). London. Available: https://beamexchange.org/uploads/filer_public/5d/4c/5d4c7b02-a25d-43ab-ae33-0e4811b7c5fb/guidance_stakeholderanalysis.pdf [accessed: October 27, 2017].

World Bank. Stakeholder Analysis (2001) Available: http://www1.worldbank. org/publicsector/anticorrupt/PoliticalEconomy/stakeholderanalysis.htm [accessed: October 27, 2017].

World Wildlife Fund. Cross Cutting Tool: Stakeholder Analysis (2005). Available: www.panda.org/standards/1_1_stakeholder_analysis/ [accessed: October 27, 2017]. 